\title{
Influence of different cultivation methods on carbohydrate and lipid compositions and digestibility of energy of fruits and vegetables
}

\author{
Henry Jørgensen, ${ }^{*}$ Knud Erik Bach Knudsen and Charlotte Lauridsen
}

\begin{abstract}
BACKGROUND: Environmental as well as cultivation factors may greatly influence the chemical composition of plants. The main factors affecting the chemical composition of foodstuff are level and type of fertilizer (conventional and organic cultivation systems), location or soil type, and year of harvest. Organic foods are defined as products that are produced under controlled cultivation conditions characterized by the absence of synthetic fertilisers and very restricted use of pesticides. Very limited information is available regarding the impact of organic cultivation systems on the composition of carbohydrates and fatty acids of fruits and vegetables. The objective was to investigate the influence of organic and conventional cultivation systems on the carbohydrate and fatty acid composition and digestibility of the energy of apple, carrot, kale, pea, potato, and rape seed oil.

RESULTS: Carbohydrate and lignin values ranged from $584 \mathrm{~g} \mathrm{~kg}^{-1}$ dry matter in kale to $910 \mathrm{~g} \mathrm{~kg}^{-1} \mathrm{DM}$ in potato, but with significant differences in the proportion of sugars, starch, non-starch polysaccharides, and lignin between the foodstuffs. Triacylglycerol was the major lipid class in pea, with $\mathbf{8 2} \%$ of total fatty acids, as opposed to apple, with only $35 \%$ of fatty acids of the ether extract. The most important factor influencing the digestibility of energy, and consequently faecal bulking, was the content of dietary fibre.
\end{abstract}

CONCLUSION: The cultivation system had minor impact on the carbohydrate and lipid composition in the investigated foodstuffs or on the digestibility of energy when assessed in the rat model. Faecal bulking was related to dietary fibre in a linear fashion. (c) 2012 Society of Chemical Industry

Keywords: organic food production; dietary fibre; fatty acids; faecal bulking

\section{INTRODUCTION}

Environmental as well as cultivation factors may greatly influence the chemical composition of plants. ${ }^{1}$ The main factors affecting the chemical composition of foodstuff are level and type of fertilizer, ${ }^{2-4}$ location or soil type, ${ }^{5,6}$ and year of harvest. ${ }^{7,8}$

Organic foods are defined as products that are produced under controlled cultivation conditions characterized by the absence of synthetic fertilizers and a very restricted use of pesticides. Few systematic scientific studies, however, are available in which the nutritional quality of organic foods has been compared with that of conventional foods under comparable and controlled conditions as reviewed by Bourn and Prescott ${ }^{9}$ and Dangaour et al. ${ }^{10}$ Among the available studies, a general conclusion has been drawn that some foods of organic origin had a general trend of a lower nitrate and a higher vitamin $C$ content than conventional vegetables. ${ }^{11-13}$ In a recent review, ${ }^{14}$ focus has been given to the content of secondary metabolites and plant defence compounds in various fruits and vegetables grown according to organic food production systems, and it was concluded that the content of secondary metabolites was approximately $12 \%$ higher in organic samples than in corresponding conventional samples. According to the author's knowledge, however, there is a lack of information regarding the impact of organic cultivation systems on the composition of carbohydrates and fatty acids compositions of fruits and vegetables.

According to glycosidic linkage, dietary carbohydrates constitute a major fraction of most foods and feeds and can be divided into sugars (mono- and disaccharides), oligosaccharides, starch, and non-starch polysaccharides (NSP). ${ }^{15} \mathrm{~A}$ thorough chemical analysis of the carbohydrate fraction can be used to distinguish carbohydrates potentially digested by endogenous enzymes in the small intestine from those that resist digestion, but which to a variable degree can be fermented by the microflora in the large intestine. ${ }^{16,17}$ The bulk of disaccharides and starch is broken down by the action of pancreatic and mucosal enzymes in the small intestine, whereas there are no enzymes capable of cleaving most oligosaccharides and NSP. A fraction of starch - resistant starch-may also pass the small intestine undegraded either because the starch is physically inaccessible due to encapsulation, molecular structure, or the starch is retrograded after heat treatment. ${ }^{18-20}$ Lignin is not a carbohydrate but is tightly

\footnotetext{
Correspondence to: Henry Jørgensen, Department of Animal Science, Aarhus University, AU-Foulum, PO Box 50, 8830 Tjele, Denmark.

E-mail: Henry.Jorgensen@agrsci.dk
}

Department of Animal Science, Aarhus University, 8830 Tjele, Denmark 
associated with cell wall polysaccharides and has a profound influence on the degradation of NSP in lignified tissues. It is now well known that an adequate intake of dietary fibre (DF, non-digestible carbohydrates plus lignin) is linked to health benefits, e.g. a protective role against large bowel cancer, diabetes, and coronary heart disease..$^{21-24}$ The faecal bulking capacity of a feedstuff or a diet is an important property because studies have shown that it is linked to the protection against a number of large bowel disorders. ${ }^{21,25}$ To experimentally measure nutrient digestibility and faecal bulking in humans, the rat has shown to be a useful model. ${ }^{26,27}$

Linoleic (C18:2 n-6) and $\alpha$-linolenic $(C 18: 3 n-3)$ are essential fatty acids which cannot be synthesized in the mammalian organism and therefore must be supplied in the diets of animals and humans. ${ }^{28}$ These fatty acids are precursors for the important longer-chain higher polyunsaturated fatty acids of the n- 6 and n-3 families. ${ }^{29}$ Furthermore, the dietary fatty acid compositions are reflected in the body fatty acid composition, ${ }^{30}$ but a proper intake of $n-3$ long-chain fatty acids has positive health implications, ${ }^{31}$ although consumption of an excess of dietary fat as a whole may exert negative effects on human weight change. ${ }^{32}$

The objective of the present study was to evaluate the influence of organic and conventional cultivation systems on the carbohydrate and fatty acid composition and digestibility of energy of apple, carrot, kale, pea, potato, and rape seed oil grown on three cultivation systems in two consecutive years.

\section{MATERIALS AND METHODS}

\section{Plant material}

The plant material was established on two locations and grown for two successive years (2001 and 2002; year 1 and year 2 , respectively). Potatoes and oilseed rape were produced at Research Centre Foulum (AU, Denmark), and carrots, kale, and mature peas at Research Centre Årslev (AU, Denmark). The rapeseeds were only grown in year 1 . The cultivation methods applied at both sites were the following: (i) a model of a distinct organic cultivation system with a low input of nutrients through animal manure and use of catch crops and no pesticides (LIminusP); (ii) a model of a distinct conventional cultivation system with a high input of nutrients through mineral fertilizer and use of as much pesticides as is allowed (HIplusP); (iii) a combination of (i) and (ii) with a low input of nutrients, primarily through animal manure, and use of as much pesticide as is allowed (LIplusP). The plant varieties used were: apple (Otava), carrot (Bolero), kale (Bona), pea (Ambassador), and potato (Sava). A more detailed description of the crop management is given by Jørgensen et $a l .^{33}$ and Kristensen et al. ${ }^{34}$ Each ingredient was processed as for application for human consumption: potatoes and mature, soaked peas and kale were boiled, and raw carrots and apples were shredded. The food was then freeze-dried and packed into airtight bags which were stored at $-20{ }^{\circ} \mathrm{C}$. Cold processed rapeseed oil was produced from the air-dried rapeseed of the three cultivation treatments from year 1 , and the residual was discarded. The processing of the ingredients was intended to ensure that the feed mixture would be stable for a long-term animal experiment.

\section{Analytical analysis}

Dry matter and ash were determined according to the Association of Official Chemists. ${ }^{35}$ Starch and sugars were analysed by the enzymatic-colorimetric methods of Bach Knudsen. ${ }^{36}$ Total NSP and their constituent sugars were determined as alditol acetates by gas-liquid chromatography (GLC) for neutral sugars by the colorimetric method for uronic acids using a modification of the Uppsala ${ }^{37}$ and Englyst et al. ${ }^{38}$ procedures as described by Bach Knudsen. ${ }^{36}$ Lignin (Klason) was determined gravimetrically as the residue resistant to hydrolysis by $2 \mathrm{~mol} \mathrm{~L}^{-1} \mathrm{H}_{2} \mathrm{SO}_{4}{ }^{37}$ Dietary lipids were extracted with diethyl ether after hydrochloric acid hydrolysis ${ }^{39}$ using petroleum ether, and long-chain fatty acids (>C8) were determined by GLC (capillary) after saponification and methylation, as described by Rotenberg and Andersen, ${ }^{40}$ with substitution of hexane with heptane, and with C17:0 as the internal standard.

\section{Animals and diets}

The Danish Animal Experiments Inspectorate, Ministry of Justice, Denmark, approved the protocol with the guide for care and use of laboratory animals. The experimental procedure with rats has been described in detail by Eggum. ${ }^{41}$ Groups of five male Wistar rats obtained from Taconic Europa (Lille Skensved, Denmark), each weighing approximately $70 \mathrm{~g}$, were adapted to their diets for 5 days followed by a balance period of 4 days during which faeces and urine were quantitatively collected. The rats were housed individually in Plexiglas cages with stainless-steel mesh floors that permitted separate collection of urine and faeces. Temperature and relative humidity were maintained at $25^{\circ} \mathrm{C}$ and $60 \%$, respectively. Alternating $12 \mathrm{~h}$ periods of light and darkness were controlled day length.

All freeze-dried experimental feed ingredients were ground through a $1 \mathrm{~mm}$ screen except apples which, because of the high content of sugar, were ground with a mortar and pestle. The diets were adjusted to $15 \mathrm{~g} \mathrm{~N} \mathrm{~kg}^{-1}$ dry matter (DM) with an $\mathrm{N}$-free mixture and by adding the necessary amounts of minerals and vitamins. $^{42}$ In the case of apple, carrots, and potatoes, where the protein content is relatively low, further casein enriched with $1 \%$ methionine was added. The reason for adding casein to the diets was to obtain $15 \mathrm{~g} \mathrm{~N} \mathrm{~kg}^{-1} \mathrm{DM}$ and increase the palatability. Throughout the adaptation and balance periods, each animal received $10 \mathrm{~g} \mathrm{DM}$ and $150 \mathrm{mg} \mathrm{N}$ per day.

\section{Calculations and statistics}

Digestibility of a given nutrient is defined as the difference between intake of the nutrient and the amount excreted in the faeces. This is normally expressed relative to the intake of that specific nutrient. In the present study, the digestibility of the experimental ingredients in the diet was calculated by the difference method, which involved a separate digestibility experiment in which the digestibility of the $\mathrm{N}$-free mixture and casein was estimated. These values were then used to calculate the digestibility of the experimental ingredients. Calculation of the digestibility of energy (DCenergy) was as follows:

$$
\begin{aligned}
& \text { DCenergy }=\text { (total digested energy } \\
& \text { - energy digested } \mathrm{N} \text {-free - energy digested casein)/ } \\
& \text { energy experimental ingredient }
\end{aligned}
$$

Analysis of variance was carried out according to a factorial design using the GLM procedure of the Statistical Analysis System software package (SAS Institute, Inc., Cary, NC, USA). The sources of variations were cultivation system and harvest year.

The relationship between the intake of DF (iDF) and faecal dry matter bulking (fDM) expressed in grams per day was analysed by 


\begin{tabular}{|c|c|c|c|c|c|c|}
\hline & & Apple & Carrot & Kale & Pea & Potato \\
\hline \multirow[t]{2}{*}{ Sucrose } & Year 1 & 149 & 318 & 10 & $60^{*}$ & 0.8 \\
\hline & Year 2 & 193 & 348 & 19 & 40 & 0.7 \\
\hline \multirow[t]{2}{*}{ Total sugars } & Year 1 & 691 & $511^{*}$ & $90^{*}$ & $76^{*}$ & $43^{*}$ \\
\hline & Year 2 & 712 & 534 & 118 & 80 & 20 \\
\hline \multirow[t]{2}{*}{ Starch } & Year 1 & $-{ }^{a}$ & - & 28 & 236 & 801 \\
\hline & Year 2 & - & - & 18 & 228 & 801 \\
\hline \multirow[t]{2}{*}{ Fructan } & Year 1 & 40 & 0.9 & 0.5 & 1.4 & 0.1 \\
\hline & Year 2 & 42 & 2.5 & 0.7 & 1.8 & 0.1 \\
\hline \multirow[t]{2}{*}{$\mathrm{NCP}$} & Year 1 & $88(55)^{b}$ & $133(104)$ & $298(211)$ & $178(64)$ & $69(43)$ \\
\hline & Year 2 & $85(54)$ & $137(110)$ & $300(214)$ & $178(81)$ & $70(44)$ \\
\hline \multirow[t]{2}{*}{ Rhamnose } & Year 1 & $1(1)$ & $4(3)$ & $7(5)$ & $2(1)$ & $1(1)$ \\
\hline & Year 2 & $1(1)$ & $4(3)$ & $7(5)$ & $3(2)$ & $1(1)$ \\
\hline \multirow[t]{2}{*}{ Fructose } & Year 1 & $1(0)$ & $0(0)$ & $3(1)$ & $1(0)$ & $0(0)$ \\
\hline & Year 2 & $1(0)$ & $0(0)$ & $3(1)$ & $1(0)$ & $0(0)$ \\
\hline \multirow[t]{2}{*}{ Arabinose } & Year 1 & $20(12)$ & $13^{*}(10)^{*}$ & $61(44)$ & $64(31)$ & $5(3)$ \\
\hline & Year 2 & $20(12)$ & $17(13)$ & $60(44)$ & $64(37)$ & $4(4)$ \\
\hline \multirow[t]{2}{*}{ Xylose } & Year 1 & $8(1)$ & $4(0)$ & $20(2)$ & $16(0)$ & $1(0)$ \\
\hline & Year 2 & $8(1)$ & $3(0)$ & $21(1)$ & $14(3)$ & $1(0)$ \\
\hline \multirow[t]{2}{*}{ Mannose } & Year 1 & $3(1)$ & $4(0)$ & $7(0)$ & $3(2)$ & $3(3)$ \\
\hline & Year 2 & $3(1)$ & $4(0)$ & $7(0)$ & $3(1)$ & $3(3)$ \\
\hline \multirow[t]{2}{*}{ Galactose } & Year 1 & $11(5)$ & $20^{*}(15)^{*}$ & $40(22)$ & $14(9)$ & $22^{*}(14)$ \\
\hline & Year 2 & $12(6)$ & $27(21)$ & $41(23)$ & $14(11)$ & $17(13)$ \\
\hline \multirow[t]{2}{*}{ Glucose } & Year 1 & $5(2)$ & $5(0)$ & $8(4)$ & $43(1)$ & $22(9)$ \\
\hline & Year 2 & $6(3)$ & $4(1)$ & $9(5)$ & $44(5)$ & $27(11)$ \\
\hline \multirow[t]{2}{*}{ Uronic acid } & Year 1 & $39(33)^{*}$ & $83(74)$ & $151(134)$ & 34 (19) & $14(12)$ \\
\hline & Year 2 & $35(30)$ & $79(72)$ & 153 (136) & $34(23)$ & $17(13)$ \\
\hline \multirow[t]{2}{*}{ Cellulose } & Year 1 & 46 & 75 & 125 & 110 & 18 \\
\hline & Year 2 & 41 & 69 & 121 & 109 & 18 \\
\hline \multirow[t]{2}{*}{ Total NSP } & Year 1 & $134 *(55)$ & 209 (104) & $423(211)$ & $288(65)$ & $86(43)$ \\
\hline & Year 2 & $127(54)$ & $207(110)$ & $421(214)$ & $286(81)$ & $87(45)$ \\
\hline \multirow[t]{2}{*}{ Lignin (Klason) } & Year 1 & 18 & 7 & 44 & 10 & 0 \\
\hline & Year 2 & 16 & 8 & 48 & 8 & 0 \\
\hline \multirow[t]{2}{*}{ Dietary fibre } & Year 1 & 153 & 216 & 466 & 299 & 86 \\
\hline & Year 2 & 143 & 214 & 469 & 294 & 88 \\
\hline \multicolumn{7}{|l|}{$\mathrm{CHO}+$ lignin } \\
\hline \multirow[t]{2}{*}{ Analysed } & Year 1 & 844 & 726 & 584 & 611 & 929 \\
\hline & Year 2 & 854 & 750 & 605 & 583 & 909 \\
\hline \multirow[t]{2}{*}{ Calculated } & Year 1 & 953 & $845^{*}$ & 671 & 671 & 881 \\
\hline & Year 2 & 958 & 873 & 686 & 666 & 879 \\
\hline
\end{tabular}

a linear regression model:

$$
Y=\beta_{0}+\beta_{1} X+\varepsilon
$$

where $Y$ is the response parameter (fDM), $\beta_{0}$ the intercept, $\beta_{1}$ the slope and $\varepsilon$ a normal distributed random variable. The relationship between the faecal bulking and the individual DF components, soluble non-cellulosic polysaccharides (NCP), insoluble NCP, cellulose, and lignin was expressed by a multiple regression model:

$$
Y=\beta_{0}+\beta_{1} X+\ldots \beta_{\nu} X \varepsilon
$$

where $Y$ is the response parameter (fDM), $\beta_{1}$ the intercept, $\beta_{1-v}$ the slope for the individual DF components, and $\varepsilon$ a normal 
Table 2. Chemical composition of the lipid fraction in dry matter of fruits and vegetables grown at three cultivation systems and two years of harvest

\begin{tabular}{|c|c|c|c|c|c|c|c|c|c|}
\hline & & & & & & & & apeseed oi & \\
\hline & & Apple & Carrot & Kale & Pea & Potato & LIminusP & HIplusP & LIplusP \\
\hline Fat & Year 1 & 9 & $15^{*}$ & 54 & 41 & 2 & 1000 & 1000 & 1000 \\
\hline$\left(\mathrm{g} \mathrm{kg}^{-1} \mathrm{DM}\right)$ & Year 2 & 7 & 6 & 55 & 41 & 3 & & & \\
\hline $\mathrm{C} 8: 0$ & Year 1 & $0^{*}$ & 0.2 & 0 & 0 & $0.1^{*}$ & 0 & 0 & 0 \\
\hline ( $\%$ of $F A)$ & Year 2 & 0.1 & 0.0 & 0 & 0.0 & 0 & & & \\
\hline $\mathrm{C} 10: 0$ & Year 1 & 0 & 0.0 & 0 & 0 & 0.0 & 0 & 0 & 0 \\
\hline & Year 2 & 0.0 & 0.0 & 0 & 0.0 & 0 & & & \\
\hline $\mathrm{C} 12: 0$ & Year 1 & $0^{*}$ & 0.1 & 0 & 0 & 0.1 & 0 & 0 & 0 \\
\hline & Year 2 & 0.3 & 0.1 & 0.2 & 0.0 & 0.1 & & & \\
\hline $\mathrm{C} 14: 0$ & Year 1 & 0.4 & 0.4 & 0.6 & 0.4 & $0.9^{*}$ & 0 & 0 & 0 \\
\hline & Year 2 & 0.9 & 0.3 & 1.3 & 0.4 & 0.8 & & & \\
\hline $\mathrm{C} 15: 0$ & Year 1 & 0.2 & 0.6 & 0.5 & 0.1 & 0.7 & 0 & 0 & 0 \\
\hline & Year 2 & 0.3 & 0.7 & 0.4 & 0.1 & 0.7 & & & \\
\hline $\mathrm{C} 16: 0$ & Year 1 & 23.0 & $25.2^{*}$ & $17.0^{*}$ & 13.3 & 39.4 & 4.3 & 4.4 & 3.8 \\
\hline & Year 2 & 20.1 & 38.5 & 18.8 & 14.9 & 39.6 & & & \\
\hline C18:0 & Year 1 & 7.7 & 2.0 & 2.7 & 3.7 & 12.5 & 1.9 & 1.9 & 1.9 \\
\hline & Year 2 & 6.2 & 2.4 & 3.1 & 3.2 & 11.2 & & & \\
\hline C18: 1 & Year 1 & 12.4 & $4.4^{*}$ & 2.7 & 32.4 & $3.4^{*}$ & 64.1 & 65.4 & 74.3 \\
\hline & Year 2 & 11.4 & 6.6 & 3.2 & 27.0 & 4.7 & & & \\
\hline C18:2 & Year 1 & 45.3 & $57.2^{*}$ & 29.1 & $44.1^{*}$ & 29.1 & 19.3 & 17.6 & 8.7 \\
\hline & Year 2 & 44.7 & 43.0 & 28.3 & 46.9 & 32.1 & & & \\
\hline $\mathrm{C} 18: 3 \mathrm{w} 3$ & Year 1 & 5.6 & $3.9^{*}$ & 47.4 & 8.5 & 6.4 & 8.3 & 8.6 & 9.1 \\
\hline & Year 2 & 9.2 & 1.7 & 44.8 & 5.5 & 4.1 & & & \\
\hline$C 20: 0$ & Year 1 & $4.1^{*}$ & 0.8 & 0 & $0^{*}$ & $2.6^{*}$ & 0.6 & 0.6 & 0.6 \\
\hline & Year 2 & 3.1 & 1.5 & 0 & 0.4 & 3.0 & & & \\
\hline C20:1w9 & Year 1 & $1.2^{*}$ & 0.7 & 0 & $0^{*}$ & 0.2 & 1.1 & 1.1 & 1.2 \\
\hline & Year 2 & 0.4 & 0.6 & 0 & 0.7 & 0.9 & & & \\
\hline $\mathrm{C} 20: 3 w 6$ & Year 1 & 0 & $0.4^{*}$ & 0 & 0 & 0 & 0 & 0 & 0 \\
\hline & Year 2 & 0 & 0 & 0 & 0 & 0 & & & \\
\hline $\mathrm{C} 22$ & Year 1 & $0^{*}$ & 3.1 & 0 & $0^{*}$ & $2.8^{*}$ & 0.3 & 0.3 & 0.3 \\
\hline & Year 2 & 2.6 & 3.3 & 0 & 0.4 & 1.2 & & & \\
\hline $\mathrm{C} 24$ & Year 1 & $0^{*}$ & $1.0^{*}$ & 0 & $0^{*}$ & $1.5^{*}$ & 0 & 0 & 0 \\
\hline & Year 2 & 0.8 & 1.3 & 0 & 0.4 & 1.3 & & & \\
\hline Sum FA & Year 1 & 0.3 & $0.7^{*}$ & 2.6 & 3.4 & 0.1 & 93.5 & 93.4 & 89.0 \\
\hline $\mathrm{g} \mathrm{kg}^{-1} \mathrm{DM}$ & Year 2 & 0.3 & 0.4 & 2.2 & 3.4 & 0.1 & & & \\
\hline Sum FA & Year 1 & 32.2 & 48.5 & 47.9 & 81.2 & 50.4 & 93.5 & 93.4 & 89.0 \\
\hline$\%$ of total fat & Year 2 & 39.2 & 59.4 & 39.8 & 83.7 & 52.4 & & & \\
\hline
\end{tabular}

distributed random variable. Stepwise forward and backward calculations were performed.

\section{RESULTS AND DISCUSSION}

In accordance with a recent published review ${ }^{10}$ of studies investigating differences in nutrient quality between organically and conventionally produced foodstuffs, there was virtually no significant differences in the present study between the three cultivation systems on most measured variables except for the fatty acid composition of rapeseed oil (Tables 1 and 2). In addition, the investigation of crude protein and amino acids in the same vegetables, which was published elsewhere, ${ }^{33}$ led to the conclusion that growing year but not cultivation system influenced the protein quality and energy value of the food. It is difficult to explain the lack of differences between cultivation methods on the carbohydrates in the present study. It cannot be excluded that cultivation methods indirectly influenced the plant maturity and therefore also the chemical composition of the plant ingredients, as the given items were harvested at the same time irrespective of cultivation system. However, the observed variation in the carbohydrate composition of the foods was due to harvest year 
rather than to cultivation method. This has been observed before; i.e. harvest year rather than genotype influenced content and composition of dietary fibre in grain. ${ }^{43,44}$ Results for the various vegetables are therefore only reported here as the mean values of the three cultivation systems and growing years.

The major part of the carbohydrates in apple and carrot derives from sugars (glucose, fructose, and sucrose), in potato from starch, in pea from NSP and starch, and in kale from NSP (Table 1). Kale also contained relatively high levels of lignin, whereas the concentration of this non-carbohydrate component was low in potato, carrot, and pea. The high levels of sugars in apple and carrot and the low levels of sugars in potato are comparable to that reported by Li et al..$^{45}$ and to the levels of sugars and starch as found for peas for feeding by Bach Knudsen. ${ }^{36}$ The level of fructan is low in carrot, kale, pea, and potato but is reasonably high in apple, as also found in other investigations. ${ }^{46-50}$ Our values reported for apple, however, are almost 10 times higher than reported by Campbell et al. ${ }^{46}$ and L'homme et al. ${ }^{47}$ It is difficult to explain why this should be the case except if different analytical techniques had been used. In this study, an analytical assay based on specific enzymes is used, whereas Campbell et al. ${ }^{46}$ and L'homme et al. ${ }^{47}$ use HPLC. A few significant differences on season were found for some of the constituents' NSP sugar residues, i.e. carrot arabinose, carrot and potato galactose. Uronic acid was somewhat higher in year 1. This also contributed to a significantly higher content of total NSP. A comparison of all vegetables but potato between analysed and calculated carbohydrates plus lignin demonstrated a high degree of correlation ( $r=0.993, P<0.0001)$ with no deviation regarding the apple samples in the present study. Cellulose represent from $21 \%$ (potato) to $39 \%$ (pea) of the NSP in the fruit and vegetables. Fruit and vegetables are known to contain high levels of soluble polysaccharides - predominantly as pectins. ${ }^{49}$. This is also found in the present study, where the absolute and relative contents of soluble NCP were high in kale, carrot, apple, and potato and with a high proportion represented by uronic acid, which is the backbone residue in pectin. In pea, insoluble NCP makes up the major part of the NCP fraction, ${ }^{36}$ which is mostly represented by insoluble glucose, xylose, and arabinose residues.

Triacylglycerol is the major lipid class in most cereals and oil seeds, whereas total fatty acids in vegetables and fruits are often less than $50 \%$ of the ether extract..$^{50}$ This is shown in Table 2, where the sum of fatty acids in apple, carrot, kale, and potato contain from one-third to $50 \%$ fatty acids of total ether extract. Pea and rapeseed, which are regarded both as protein and oil seeds, contain from $80 \%$ to $94 \%$ fatty acids in total ether extract. The C18 family and C16:0 were the most predominant fatty acids in the total ether extract, and in apple, carrot, and pea linoleic acid contributed approximately $50 \%$ of the total fatty acids. In terms of the ratio of $n-6$ to $n-3$, which is considered important from a human health perspective, ${ }^{29}$ kale had the lowest ratio (1.6) and carrot the highest (17.8).

As expected, rapeseed oil had the highest concentration of fatty acids, which was far beyond that of the other vegetables. Although rape was cultivated only one year, and statistical analysis was therefore not appropriate, it should be noted that the fatty acid composition and content of the rapeseed oil of LIplusP differed in comparison with the other cultivation systems; i.e. the content of total fatty acids was lower, and the relative proportion of $\mathrm{C} 18: 1$ was higher at the expense of mainly $C 18: 2$. When included in complete diets for rats providing $25 \%$ of the energy content, ${ }^{51}$ the differences in fatty acid composition between cultivation systems were clearly reflected in the fatty acid composition of the tissue

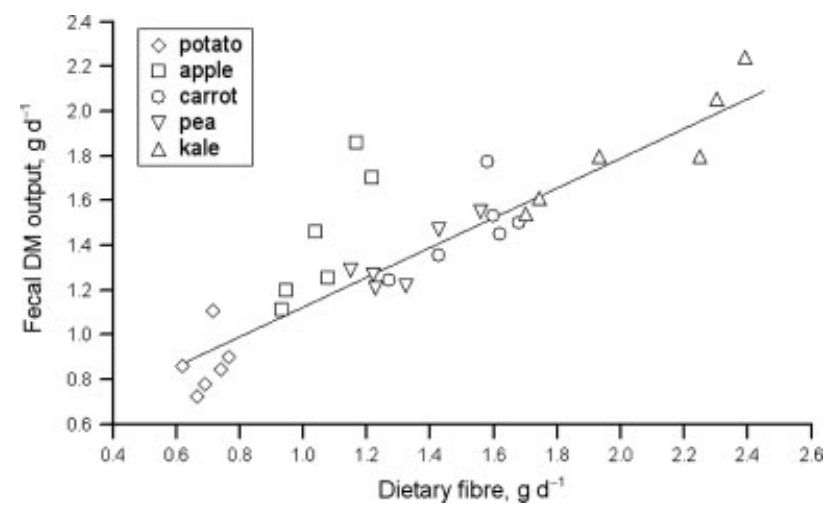

Figure 1. Effect of intake of dietary fibre on faecal bulking in rats fed diets containing the listed vegetables. All rats had an equal amount of consumed feed daily.

of the rats. In addition to the changed fatty acid content, it was also observed that the oil of LIplusP had a lower content of $\alpha$ - and $\gamma$-tocopherol ${ }^{51}$ and was more green in colour than the rapeseed oil of the other cultivation systems, indicating a higher content of chlorophyll. Probably, the oil of LIplusP contained an elevated content of free fatty acids which was more susceptible toward oxidation resulting in a decrease of the vitamin E content and a change in the fatty acid composition.

DF is defined as the carbohydrates and lignin that are not digested by the endogenous enzymes in the small intestine of humans (and other mammals), ${ }^{52}$ and it is therefore not surprising to find that DF has a direct influence on faecal dry matter output, as illustrated in Fig. 1, ${ }^{53 ; 54}$ and on the digestibility of DM (energy) of the diet (Table 3). ${ }^{33,55}$ The bulking properties are first and foremost determined by the intake of DF and are expressed by the following equation:

$$
\mathrm{fDM}=0.49+0.67 \times \mathrm{iDF}, R^{2}=0.77, P<0.0001
$$

An analysis of the individual DF components contributing to faecal bulking demonstrated that lignin ( $L$ ) and cellulose (Cell) were the two most important contributors, whereas the contributions from soluble and insoluble NCP were not significant. The equation can be expressed as follows:

$$
\mathrm{fDM}=0.66+0.77 \times \text { Cell }+2.76 \times L, R^{2}=0.81, P<0.0001
$$

The multiple regression analysis model, however, only showed a marginal further improvement in model prediction compared to the linear model.

The faecal bulking capacity of a feedstuff or a diet is an important property, because it may be linked indirectly to the protection against a number of large bowel disorders, primarily because non-digestible components dilute the colonic content and reduce transit time. These factors are associated with wellbeing in Western society. ${ }^{25}$ Moreover, although it has been difficult to establish a direct link between the intake of DF and colorectal cancer, ${ }^{55,57}$ a diet high in DF from whole plant foods is still advised because it has been related to a lower risk of other chronic diseases..$^{21-24}$

In conclusion, the cultivation system had a minor impact on carbohydrate and lipid composition in vegetables and fruits typically consumed in human nutrition. In addition, no influence was obtained with regard to the digestibility of energy from the 
Table 3. Diet and chemical composition, DM intake and energy digestibility

\begin{tabular}{|lrrrrr|} 
& Apple & Carrot & Kale & Pea & Potato \\
\hline Year 1 & & & & & \\
Vegetable item (\%) & 78.7 & 77.1 & 47.9 & 36.8 & 76.3 \\
Casein & 10.4 & 3.8 & - & - & 3.9 \\
N-free mixture & 6.3 & 14.1 & 46.7 & 57.8 & 14.7 \\
Vit. min. mixture & 4.6 & 5.0 & 5.4 & 5.4 & 5.1 \\
Chemical composition (g & & & & & \\
$\quad$ kg $^{-1}$ ) DM & & & & & \\
Protein (N $\times 6.25)$ & 134 & 98 & 97 & 100 & 114 \\
Dietary fibre & 143 & 196 & 267 & 151 & 80 \\
DM intake (g d ${ }^{-1}$ ) & 8.9 & 8.0 & 7.0 & 8.9 & 9.6 \\
Energy digestibility (\%) & 81.6 & 84.5 & 75.9 & 84.4 & 93.1 \\
Year 2 & & & & & \\
Vegetable item (\%) & 63.2 & 73.4 & 53.8 & 35.9 & 58.4 \\
Casein & 8.9 & 4.8 & - & - & 5.1 \\
N-free mixture & 22.6 & 16.6 & 40.8 & 58.7 & 31.1 \\
Vit. min. mixture & 5.3 & 5.2 & 5.4 & 5.4 & 5.4 \\
Chemical composition (g & & & & & \\
$\quad$ kg ${ }^{-1}$ ) DM & & & & & \\
Protein (N $\times 6.25)$ & 97 & 105 & 102 & 99 & 102 \\
Dietary fibre & 114 & 184 & 296 & 147 & 73 \\
DM intake (g d ${ }^{-1}$ ) & 9.1 & 9.3 & 8.1 & 9.1 & 9.3 \\
Energy digestibility (\%) & 87.8 & 86.4 & 74.3 & 85.9 & 93.4 \\
\hline
\end{tabular}

foodstuffs in question when assessed in the rat model. The dietary concentration, however, had a direct impact on faecal bulking.

\section{ACKNOWLEDGEMENTS}

The Danish Research Centre for Organic Farming (DARCOF), Tjele, Denmark, is acknowledged for financial support of this study. Kathrine Hansen Høirup and Benny Thomasen are acknowledged for their technical assistance to the study.

\section{REFERENCES}

1 Eppendorfer WH and Bille SW, Free and total amino acid composition of edible parts of beans, kale, spinach, cauliflower and potatoes as influenced by nitrogen fertilisation and phosphorus and potassium deficiency. J Sci Food Agric 71:449-458 (1996).

2 Eppendorfer WH and Eggum BO, Effects of nitrogen, phosphorus, sulphur, potassium, calcium and water stress on yield, mineral and amino acid composition, dietary fibre and nutritive value of carrots. Acta Agric Scand Sect B 45:124-131 (1995).

3 Greenwood DJ and Hunt J, Effect of nitrogen-fertilizer on the nitrate contents of field vegetables grown in Britain. J Sci Food Agric 37:373-383 (1986).

4 Jørgensen H, Gabert VM and Fernández JA, Influence of nitrogen fertilization on the nutritional value of high-lysine barley determined in growing pigs. Anim Feed Sci Technol 79:79-91 (1999).

5 Bach Knudsen KE, Åman P and Eggum BO, Nutritive value of Danish-grown barley varieties. I. Carbohydrates and other major constituents. J Cereal Sci 6:173-186 (1987).

6 Just A, Jørgensen H, Fernández JA and Jepsen HM, Feed value of spring barley, winter barley and winter wheat for pigs and the influence of type of soil and nitrogen fertilization on the feed value. National Institute of Animal Science, Copenhagen (1983).

7 Brunsgaard G, Kidmose U, Sorensen L, Kaack K and Eggum BO, The influence of variety and growth conditions on the nutritive value of carrots. J Sci Food Agric 65:163-170 (1994).
8 Canibe N, Bach Knudsen KE and Eggum BO, Digestibility and nitrogen balance in rats given dried or toasted peas (Pisum sativum) of different years of harvest. J Sci Food Agric 73:21 - 33 (1997).

9 Bourn D and Prescott J, A comparison of the nutritional value, sensory qualities, and food safety of organically and conventionally produced foods. Crit Rev Food Sci Nutr 42:1 - 34 (2002).

10 Dangour AD, Dodhia SK, Hayter A, Allen E, Lock K and Uauy R, Nutritional quality of organic foods: a systemetic review. Am J Clin Nutr 90:680-685 (2009).

11 Warman PR and Havard KA, Yield, vitamin and mineral contents of organically and conventionally grown carrots and cabbage. Agric Ecosys Environ 61:155-162 (1997).

12 Woese K, Lange D, Boess C and Bogl KW, A comparison of organically and conventionally grown foods: results of a review of the relevant literature. J Sci Food Agric 74:281 - 293 (1997).

13 Wolfson JL and Shearer G, Amino acid composition of grain protein of maize grown with and without pesticides and standard commercial fertilizers. Agron J 73:611-613 (1981).

14 Brandt K, Leifert C, Sanderson R and Seal CJ, Agroecosystem management and nutritional quality of plant foods: the case of organic fruits and vegetables. Crit Rev Plant Sci 30:177-197 (2011).

15 Cummings $\mathrm{JH}$ and Stephen AM, Carbohydrate terminology and classification. Eur J Clin Nutr 61:S5-S18 (2007).

16 Bach Knudsen KE and Jørgensen $\mathrm{H}$, Intestinal degradation of dietary carbohydrates: from birth to maturity, in Digestive Physiology of Pigs, ed. by Lindberg JE and Ogle B. CABI Publishing, Wallingford, UK, pp. 109-120 (2001).

17 Englyst KN, Liu S and Englyst HN, Nutritional characterization and measurement of dietary carbohydrates. Eur J Clin Nutr 61:S19-S39 (2007).

18 Englyst HN, Kingman SM and Cummings JH, Classification and measurement of nutritionally important starch fractions. Eur J Clin Nutr 46:S33-S50 (1992).

19 Hoover R and Zhou Y, In vitro and in vivo hydrolysis of legume starches by $\alpha$-amylase and resistant starch formation in legumes: a review. Carbohydr Polym 54:401-417 (2003).

20 Sun $\mathrm{T}$, Laerke HN, Jorgensen $\mathrm{H}$ and Knudsen KEB, The effect of extrusion cooking of different starch sources on the in vitro and in vivo digestibility in growing pigs. Anim Feed Sci Technol 131:66-85 (2006).

21 Cummings JH, Edmond LM and Magee EA, Dietary carbohydrates and health: do we still need the fibre concept? Clin Nutr Suppl 1:5-17 (2004).

22 Eastwood MA and Morris ER, Physical properties of dietary fiber that influence physiological function: a model for polymers along the gastrointestinal tract. Am J Clin Nutr 55:436-442 (1992).

23 Monro JA, Adequate intake values for dietary fibre based on faecal bulking indexes of 66 foods. Eur J Clin Nutr 58:32-39 (2004).

24 Weickert MO and Pfeiffer AFH, Metabolic effects of dietary fiber consumption and prevention of diabetes. J Nutr 138:439-442 (2008).

25 Monro JA and Martinet E, Functional food design based on a virtual food component: wheat bran equivalents for faecal bulk. J Sci Food Agric 85:902-908 (2005).

26 Bach Knudsen KE, Wisker E, Daniel M, Feldheim W and Eggum BO, Digestibility of energy, protein, fat and non-starch polysaccharides in mixed diets: comparative studies between man and the rat. $\mathrm{Br} J$ Nutr 71:471 -487 (1994).

27 Edwards CA, Adiotomre J and Eastwood MA, Dietary fibre: the use of in-vitro and rat models to predict action on stool output in man. J Sci Food Agric 59:257-260 (1992).

28 Givens DI, Cottrill BR, Davies M, Lee PA, Mansbridge RJ and Moss AR, Sources of $n-3$ polyunsaturated fatty acids additional to fish oil for livestock diets: a review. Nutr Abstracts Rev Series B 70:1 - 19 (2000).

29 Jakobsen K, Dietary modifications of animal fats: status and future perspectives. Fett/Lipid 101:475-483 (1999).

30 Jørgensen $\mathrm{H}$, Jensen SK and Eggum BO, The influence of rapeseed oil on digestibility, energy metabolism and tissue fatty acid composition in pigs. Acta Agric Scand Sect A 46:65-75 (1996).

31 Nettleton JA and Katz R, n-3 long-chain polyunsaturated fatty acids in type 2 diabetes: a review. J Am Diet Assoc 105:428-440 (2005).

32 Howard BV, Manson JE, Stefanick ML, Beresford SA, Frank G, Jones B, et al, Low-fat dietary pattern and weight change over 7 years: the Women's Health Initiative Dietary Modification Trial. JAMA 295:39-49 (2006). 
33 Jørgensen $\mathrm{H}$, Brandt $\mathrm{K}$ and Lauridsen $\mathrm{C}$, Year rather than farming system influences protein utilization and energy value of vegetables when measured in a rat model. Nutr Res 28:866-878 (2008).

34 Kristensen M, Østergaard LF, Halekoh U, Jørgensen H, Lauridsen C, Brandt $\mathrm{K}$, et al, Effect of plant cultivation methods on content of major and trace elements in foodstuffs and retention in rats. $J \mathrm{SCi}$ Food Agric 88:2161-2172 (2008).

35 Association of Official Analytical Chemists, Official Methods of Analysis. AOAC, Arlington, VA (1990).

36 Bach Knudsen KE, Carbohydrate and lignin contents of plant materials used in animal feeding. Anim Feed Sci Technol 67:319-338 (1997).

37 Theander $\mathrm{O}$ and Åman P, Studies on dietary fibres. 1. Analysis and chemical characterization of water-soluble and water-insoluble dietary fibres. Swedish J Agric Res 9:97-106 (1979).

38 Englyst $\mathrm{H}$, Wiggins $\mathrm{HS}$ and Cummings $\mathrm{JH}$, Determination of the non-starch polysaccharides in plant foods by gas-liquid chromatography of constituent sugars as alditol acetates. Analyst 107:307-318 (1982).

39 Stoldt W, Vorslag zur Vereinheitlichung der Fettbestimmung in Lebensmitteln. Fett Wiss Technol 54:206-207 (1952).

40 Rotenberg $\mathrm{S}$ and Andersen JO, The effect of dietary citrus pectin on fatty acid balance and the fatty acid content of the liver and small intestine in rats. Acta Agric Scand 30:8-12 (1980).

41 Eggum BO, A Study of Certain Factors Influencing Protein Utilization in Rats and Pigs. Forsøgslaboratoriet, Copenhagen (1973).

42 Jørgensen $\mathrm{H}$, Gabert VM and Eggum BO, The nutritional value of highlysine barley determined in rats, young pigs and growing pigs. J Sci Food Agric 73:287-295 (1997).

43 Hansen HB, Rasmussen CV, Bach Knudsen KE and Hansen A, Effects of genotype and harvest year on content and composition of dietary fibre in rye (Secale cereale L.) grain. J Sci Food Agric 83:76-85 (2003).

44 O'Brien L, Genotype and environment effects on feed grain quality. Aust J Agric Res 50:703-719 (1999).

45 Li BW, Andrews KW and Pehrsson PR, Individual sugars, soluble, and insoluble dietary fiber contents of 70 high consumption foods. J Food Compos Anal 15:715-723 (2002).

46 Campbell JM, Bauer LL, George C, Hogarth AJCL, Wolf BW and Hunter DE, Selected fructooligosaccharide (1-kestose, nystose, and $1^{\mathrm{F}}$ - $\beta$-fructofuranosylnystose) composition of foods and feeds. J Agr Food Chem 45:3076-3082 (1997).
47 L'homme C, Peschet JL, Puigserver A and Biagini A, Evaluation of fructans in various fresh and stewed fruits by high-performance anion-exchange chromatography with pulsed amperometric detection. J Chomatogr A 920:291-297 (2001).

48 Muir JG, Fructan and free fructose content of common Australian vegetables and fruit. J Agric Food Chem 55:6619-6627 (2007).

49 Englyst HN, Bingham SA, Runswick SA, Collinson E and Cummings JH, Dietary fibre (non-starch polysaccharides) in fruit, vegetables and nuts. J Hum Nutr Diet 1:247-286 (1988).

50 Saxholt E, Christensen AT, Møller A, Hartkopp HB, Hess Ygil K and Hels OH, Danish Food Composition Databank, version 7. Technical University of Denmark, Department of Nutrition, National Food Institute (2009).

51 Lauridsen C, Young C, Halekoh U, Bügel SH, Brandt K, Christensen LP, et al, Rats show differences in some biomarkers of health when eating diets based on ingredients produced with three different cultivation strategies. J Sci Food Agric 88:720-732 (2008).

52 Cummings $\mathrm{JH}$, Mann Jl, Nishida $\mathrm{C}$ and Vorster HH, Dietary fibre: an agreed definition. Lancet 373:365-366 (2009).

53 Cummings JH, Branch W, Jenkins DJA, Soutgate DAT, Houston $\mathrm{H}$ and James WPT, Colonic response to dietary fiber from carrot, cabbage, apple, bran, and guar gum. Lancet 1:5-9 (1978).

54 Cummings $\mathrm{JH}$, Bingham SA, Heaton $\mathrm{KW}$ and Eastwood MA, Fecal weight, colon cancer risk, and dietary intake of nonstarch polysaccharides (dietary fiber). Gastroenterology 103:1783-1789 (1992).

55 Bach Knudsen KE and Hansen I, Gastrointestinal implications in pigs of wheat and oat fractions. 1. Digestibility and bulking properties of polysaccharides and other major constituens. Br J Nutr 65:217-232 (1991).

56 Fuchs CS, Giovannucci EL, ColditzGA, Hunter DJ, Stampfer MJ, Rosner B, et al, Dietary fiber and the risk of colorectal cancer and adenoma in women. New Engl J Med 340:169-176 (1999).

57 Park $Y$, Hunter $D J$, Spiegelman $D$, Bergkvist $L$, Berrino $F$, van den Brandt PA, et al, Dietary fiber intake and risk of colorectal cancer: a pooled analysis of prospective cohort studies. J Am Med Assoc 294:2849-2857 (2005). 